\title{
ESCRITAS DA DEGENERAÇÃO: O GÓTICO E A DECADÊNCIA EM $O$ REI FANTASMA (1895), DE COELHO NETO ${ }^{1}$
}

\section{DEGENERATION WRITINGS: GOTHIC AND DECADENCE IN $O$ REI FANTASMA (1895), BY COELHO NETO}

\author{
Daniel Augusto Pereira Silva
}

\begin{abstract}
RESUMO: O objetivo deste artigo é analisar como a temática da degeneração está presente no romance "O Rei Fantasma" (1895), de Coelho Neto. Partimos da hipótese de que a narrativa é um exemplo ilustrativo da confluência entre as poéticas gótica e decadente, além de reveladora das ansiedades da época em relação à escravidão e ao imaginário orientalista. Inicialmente, investigamos como a ficção do final do século XIX explorou sistematicamente a ideia de degradação individual e coletiva. Em seguida, apresentamos a recepção crítica ao texto, segundo a qual as duas formas artísticas seriam contrárias à tradição cultural brasileira. Por fim, examinamos os procedimentos narrativos e estilísticos característicos do gótico e da decadência que estruturam a obra.
\end{abstract}

PALAVRAS-CHAVE: decadentismo; orientalismo; escravidão; literatura brasileira

ABSTRACT: This paper aims at analyzing the theme of degeneration in the novel "O Rei Fantasma" (1895), by Coelho Neto. We defend the hypothesis that the narrative is an illustrative example of the confluence between the gothic and decadent poetics and also reveals the anxieties of the time concerning slavery and the Orientalist imaginary. At first, we investigate how the fiction of the late 19th century systematically explored the idea of individual and collective degradation. Then, we present the critical reception to the text, according to which the two artistic forms were contrary to the Brazilian cultural tradition. Finally, we examine the narrative and stylistic procedures characteristic of the Gothic and the decadence that structures the work.

KEYWORDS: decadentism; orientalism; slavery; brazilian literature

\section{Os fantasmas da degeneração}

Um dos temas fundamentais da produção literária do final do século XIX é o medo da degeneração. Em diferentes literaturas nacionais, escritores representaram os mais diversos

\footnotetext{
${ }^{1}$ O presente trabalho foi realizado com apoio da Coordenação de Aperfeiçoamento de Pessoal de Nível Superior - Brasil (CAPES) - Código de Financiamento 001

${ }^{2}$ Doutorando em Teoria da Literatura e Literatura Comparada na UERJ e bolsista CAPES. Integra o Grupo de Pesquisa Estudos do Gótico (CNPq).
} 
temores de bestialização do ser humano e de corrupção social. Para muitos intelectuais e artistas, as sociedades passariam por um acelerado processo de decadência de valores religiosos, éticos e estéticos. Nesse contexto de desconfiança em relação às transformações trazidas pela modernidade, surge um conjunto de narrativas marcadas pelo pessimismo e voltadas para a produção de efeitos de recepção negativos, como o medo e a repulsa. Degradadas física e moralmente, suas personagens costumam viver em espaços decrépitos, cometem crimes e são vítimas de um profundo mal-estar existencial.

Ao analisar a ficção de terror do período no Reino Unido, David Punter (1996, p. 1) identifica a confluência entre duas formas artísticas - o gótico e a decadência -, que teriam dado forma a um "Gótico decadente". A partir da união de temas e convenções artísticas de ambas as poéticas, teriam ganhado forma algumas das principais obras vitorianas, entre elas $O$ médico e o monstro (1886), de Robert L. Stevenson; O retrato de Dorian Gray (1891), de Oscar Wilde; A ilha do Dr. Moreau (1896), de H. G. Wells; e Drácula (1897), de Bram Stoker. Apesar das diferenças entre as quatro narrativas, todas elas veiculam uma sensação de decadência generalizada, tanto dos indivíduos quanto da coletividade:

Ao olharmos para esses livros, podemos ver certa interconexão - pelo menos em termos de temas, mesmo se as posturas dos autores possam ser bem diferentes -, mas uma coisa pode ser dita desde o início, que sublinha o sentido da decadência em relação a esses textos: todos eles estão preocupados, de um jeito ou de outro, com o problema da degeneração e, portanto, com o da essência do humano. Cada um deles coloca, a partir de ângulos muito diferentes, a mesma questão, que pode facilmente ser lida como uma questão apropriada para uma era de declínio imperial: quanto, eles perguntam, alguém pode perder - individualmente, socialmente, nacionalmente - e ainda permanecer um "homem"? É possível formular a questão de modo muito mais brutal: a que ponto alguém pode ser "infectado" e ainda permanecer britânico? (PUNTER, 1996, p. 1) ${ }^{3}$

Em cada um dos romances listados, os processos de desumanização e de corrupção moral seriam representados de uma forma específica, que revelaria algumas das ansiedades mais difundidas na época. As interpretações de escritores das teorias de Darwin, por exemplo, levariam à percepção não apenas da proximidade do homem em relação a outros animais, mas também à crença de uma possibilidade de involução dos seres. Punter (1996, p. 13) indica como o medo da reversão da cadeia evolutiva - e, por extensão, da animalização do ser humano estaria presente, sobretudo, em tramas voltadas para o imperialismo britânico, supostamente ameaçado por invasões de estrangeiros perniciosos, como no romance de Wells. Outras narrativas enfatizariam como as convenções sociais falham em conter plenamente os

\footnotetext{
${ }^{3}$ Todas as traduções das citações de obras indicadas na bibliografia em língua estrangeira são de minha autoria.
} 
comportamentos dos indivíduos e, em especial, as práticas sexuais, entendidas como potencialmente degradantes, perceptíveis em Drácula e em $O$ retrato de Dorian Gray. Por essa configuração, o temor do Outro - em razão de diferenças sexuais, étnico-raciais ou sociais caracterizaria a literatura finissecular.

Amplamente difundida no final do século XIX, a noção de decadência não se limitou a um grupo reduzido de obras e temas. Como revela Stephen Arata (1996, p. 2), “até mesmo em seus usos menos extremos, a teoria da degeneração permitia que os escritores se movessem com facilidade por uma ampla gama de assuntos". Todos os campos do saber, produções artísticas, acontecimentos políticos e comportamentos humanos estavam suscetíveis de serem interpretados sob a perspectiva do declínio. Não por acaso, um dos livros mais comentados na imprensa da época era o estudo Degeneração (1892), de Max Nordau (cf. ARATA, 1996, p. 54). Além de cobrir conteúdos muito distintos entre si, a temática perpassava diferentes públicos. Segundo ainda o mesmo crítico, a percepção de degeneração teria superado, no Reino Unido, os debates de intelectuais e adquirido a forma de um saber popular, difundido por variados grupos sociais e presente também na literatura de entretenimento.

Entre os tipos de decadência, a degradação física ocupou posição de destaque nas narrativas do período. Ao examinar as recorrências estruturais da ficção de horror vitoriana e, em especial, da obra de Arthur Machen, o pesquisador Roger Luckhurst (2016, p. 107) destaca três aspectos característicos dessas produções: “[...] as novas formas que a escrita adquiriu no fim da era vitoriana; o enfraquecimento dos terrores religiosos e o surgimento de formas mais seculares de horror; e [...] o corpo como locus do horror moderno". Tais textos explorariam as variadas formas de corrupção corporal - causadas, sobretudo, por doenças e atividades sexuais julgadas desviantes - a fim de demonstrar a proximidade entre o ser humano e outras espécies de animais. Desejava-se indicar, igualmente, como os impulsos eram ameaças aos ideais de progresso e de civilização. Para tanto, os autores fariam uso sistemático de técnicas literárias para gerar repulsa e descreveriam, de forma cada vez mais explícita, personagens cujos corpos estariam infectados ou simplesmente degradados.

Em reiteradas vezes, o temor do retorno a um estado primitivo da existência recebeu uma conotação sociopolítica, particularmente em narrativas voltadas para as consequências do imperialismo. Ao examinar o gótico na década de 1890, Glennis Byron (2003, p. 187) destaca textos como o romance The Beetle (1897), de Richard Marsh, nos quais ex-colônias britânicas são vistas como ameaças: "Do Oriente, aqui descrito como o local de caos e barbarismo, em oposição ao civilizado e ordenado mundo do Ocidente, surge ‘o Besouro', também referenciado 
como 'a Mulher das Canções' ou, simplesmente, 'o Oriental'”. Na obra, a figura monstruosa, pertencente ao antigo Egito, não se limita ao seu local de origem e, tal qual ocorre em Drácula, move-se em direção a Londres. Nesses casos, a ameaça de degeneração não está restrita apenas aos indivíduos e a suas saúdes físicas, mas a toda a nação e à própria cultura da metrópole. É relevante destacar como tais narrativas recuperam, ainda, alguns temas e escolhas estilísticas consagrados por Vathek (1786), romance gótico de William Beckford, célebre por seu orientalismo ${ }^{4}$ e pela crueldade de algumas personagens.

Presente desde as origens do gótico, o imaginário de um Oriente bárbaro e violento também foi amplamente explorado pela literatura finissecular e, com frequência, apresentou-se como um traço estruturante de todos os elementos da narrativa, para além de simples referência imagética. Ao identificar essa tendência na ficção decadente, Jean Pierrot (1977, p. 57) comenta que, a partir de obras como Salammbô (1862) e La Tentation de Saint-Antoine (1874), de Flaubert, "nascerá toda uma corrente de narrativas que operarão um duplo estranhamento, no tempo e no espaço, situando as suas intrigas no Oriente mais ou menos mítico do final das civilizações antigas e das origens do cristianismo". Entre os conteúdos associados aos povos orientais na produção literária do final do século XIX, estão o exotismo, a luxúria, a corrupção moral e a crueldade. Ao desenvolverem tramas localizadas no Egito dos faraós, no Império Babilônico ou na China lendária, os escritores traçavam paralelos entre o declínio histórico dessas sociedades - normalmente, conferido a uma fragilidade de valores morais e à degradação de comportamentos sexuais - e o destino das próprias nações. A dissolução política e as crises das comunidades orientais funcionariam como reflexo dos vícios das metrópoles e como alerta para os perigos de contaminação entre os povos.

Além de patente nas representações negativas do corpo e do Oriente, a percepção de degeneração foi relacionada pelos críticos às opções discursivas de grande parte da fícção finissecular. Com uma série de experimentações textuais, a literatura decadente se desvia de usos linguísticos consagrados e facilmente compreensíveis pelos leitores. A partir da criação de neologismos, do uso de inversões sintáticas e do emprego de termos de campos semânticos de especialidades variadas, as narrativas da decadência concebiam a língua como um objeto artístico em si mesma, sujeita a ornamentações e modificações de todo tipo. Para muitos autores, o objetivo era atentar contra uma recepção que identificava nessas formas idiomáticas

\footnotetext{
${ }^{4}$ Ao longo deste artigo, empregamos a noção de "orientalismo" em sua acepção mais geral, como uma atração por temas, personagens e costumes associados ao Oriente.
} 
uma degradação dos bons usos linguísticos. Assim, a abordagem da degeneração se dava tanto pela figuração de personagens monstruosas quanto pelo desenvolvimento de um estilo de escrita deliberadamente hermético. A esse respeito, Evanghélia Stead (2004) aponta para

os laços que unem a noção de decadência à noção de deformação e à existência de um léxico, de uma escrita e de uma forma de considerar a linguagem especificamente. A hibridez que a Decadência reivindica se refere tanto à botânica quanto à gramática. A gênese de monstros repousa, pois, sobre uma dupla perturbação da ordem, natural ou fisiológica, por um lado, e linguística por outro. (STEAD, 2004, p. 12)

A temática da degeneração não ficou restrita às literaturas europeias e também se manifestou na produção brasileira. Para analisar como os temores de degradação pessoal e coletiva se revelam no Brasil do final do século XIX, analisaremos o romance O Rei Fantasma (1895), de Coelho Neto, e a sua recepção pela crítica nacional. Partimos da hipótese de que a narrativa é um exemplo ilustrativo da confluência entre as poéticas gótica e decadente, bem como reveladora das ansiedades da época. Para explicitar as diferentes formas de representação de decadência na obra, demonstraremos como o autor maranhense se valeu de um conjunto de procedimentos típicos das duas formas artísticas, dos quais se destacam: i) a criação de locus horribilis, isto é, de espaços ficcionais arruinados e ameaçadores; ii) a figuração de personagens com aspectos monstruosos; iii) a percepção do passado como um tempo ameaçador, que insiste em assombrar o presente; iv) a utilização de uma linguagem estetizada e ornamental; v) o desenvolvimento de cenas de violência explícita, com descrição minuciosa da degradação física (cf. PUNTER, 1996; FRANÇA, 2017).

\section{A crítica contra as "degenerescências literárias"}

Entre os diversos romances de Coelho Neto caídos em esquecimento, sem reedições ou numerosa bibliografia crítica, O Rei Fantasma ocupa uma posição ainda mais periférica. Publicado, inicialmente, em 1893, sob a forma de folhetim, no jornal O Paiz, ele contou apenas com uma versão em livro, dois anos depois, pela Livraria Moderna, com algumas modificações em relação ao texto anteriormente veiculado na imprensa. Nem mesmo as iniciativas, já na segunda metade do século XX, voltadas para o resgate da vasta obra do escritor, identificaram valor literário na narrativa e, assim, não a incluíram em seus projetos. Ao participar da organização do primeiro tomo da produção romanesca do maranhaense, em Obra seleta, Brito Broca (1958, p. 12-13) justifica a ausência do texto por duas razões: i) a ausência de exemplares disponíveis para consulta, até mesmo no acervo da Biblioteca Nacional; e ii) a suposta falta de 
importância da composição no conjunto dos trabalhos do autor, pois, dotado de uma estrutura folhetinesca, teria "o objetivo essencial de divertir o público".

Embora o romance esteja disponível, atualmente, apenas em edições de difícil acesso e tenha recebido pouquíssima atenção dos estudos literários contemporâneos, a sua publicação chamou a atenção tanto do público leitor quanto da crítica oitocentistas. O próprio Broca (1958, p. 12) aponta para um possível êxito comercial dos volumes folhetinescos do escritor à época, ao comentar que leu "há muito tempo essas obras, cujas primeiras edições logo se esgotaram". Uma consulta aos dados da plataforma da hemeroteca da Biblioteca Nacional parece sustentar essa hipótese. Ao longo da última década do século XIX, identificam-se diversos anúncios de O Rei Fantasma em periódicos de diferentes estados brasileiros, tais como Jornal de Recife (PE), Diário do Maranhão (MA), O Comércio de São Paulo (SP) e A Semana (RJ). É relevante indicar que, apesar de o livro ter sido publicado com a assinatura de Anselmo Ribas em sua capa, o pseudônimo era facilmente associado a Coelho Neto, já que os jornais costumam exibir, em seus reclames, o nome do escritor como sendo o do efetivo criador do romance.

Além de majoritariamente elogiosas, as críticas publicadas na imprensa apontam para aspectos centrais da narrativa, em especial para a sua tendência ao exótico, ao macabro e à exploração sistemática da violência. A obra recebeu comentários até mesmo de Machado de Assis, cujos apontamentos foram publicados em sua coluna “A Semana”, na Gazeta de Notícias, em 08 de setembro de 1895. Além de comparar, brevemente, a recriação do antigo Egito de Coelho Neto à de Cartago feita por Gustave Flaubert em Salammbô, o escritor destaca o exotismo da obra, a vivacidade da imaginação do romancista para criar tal universo e os procedimentos típicos desse tipo de história, como o recurso a uma tradução de suposto manuscrito antigo como fonte da narração. Assis (1895, p. 1) elogia, sobretudo, as descrições do romance, capazes de afetar os leitores por sua crueza: "Há quadros terríveis; a cena de Amany e da concubina tem grande movimento, e o suplício desta dói ao ler, tão viva é a pintura da moça, agarrada aos ferros e fugindo aos leões". O que mais se ressalta na avaliação machadiana é a expressividade das cenas, que enfatizam os detalhes mais violentos da narrativa.

Araripe Júnior expressou uma recepção análoga em seu longo ensaio "Movimento de 1893: crepúsculo dos povos", primeiramente publicado em A Semana, em 1894, e, depois, em 1896, editado em livro homônimo. O sexto capítulo de sua investigação se dedica a analisar o que chama de "demonismo no romance" e "degenerescência literária" (ARARIPE JÚNIOR, 1896, p. 132). Embora haja uma seção dedicada a outro romance de Coelho Neto, A Capital Federal (1893), as reflexões do crítico partem, inicialmente, de O Rei Fantasma. Pela 
tematização de civilizações antigas, de temas fantásticos e do ocultismo, o romancista é comparado a Joséphin Péladan - autor de obras decadentes, como Le Vice Suprême (1884).

Araripe Júnior não se limita às comparações com artistas estrangeiros e promove uma análise das tendências culturais brasileiras. $\mathrm{O}$ argumento principal de sua crítica se baseia na ideia de que o Brasil não seria propício para o desenvolvimento de uma literatura voltada para efeitos de recepção negativos. Para fundamentar o raciocínio, o autor se vale de uma justificativa tanto histórica quanto geográfica. Ao contrário de nações europeias como a França, o Reino Unido e a Itália, nosso país não passou por determinados processos sociais, como a Idade Média, cujos eventos, ambientações e tipos sociais são frequentemente evocados em tradições poéticas sombrias, como o gótico e a decadência. Sem a experiência histórica prévia, seriam falsas as tentativas de criar tramas que dialogassem com tais conteúdos. Além da ausência desse passado, a própria geografia nacional, marcada por vegetações esplendorosas e por altas temperaturas, funcionaria como entrave a criações ficcionais que valorizam o terror e o mal em detrimento da alegria e do bem:

\footnotetext{
Nós, brasileiros, não temos Idade Média, nem antiguidades célticas, nem ao alcance mistérios do Oriente. $\mathrm{O}$ esplendor da terra não nos permite certos caprichos; as solicitações dos trópicos anulam todos os esforços neste sentido. Faltam-nos o cansaço do presente e principalmente os espetáculos de ruínas e a sugestão dos museus [...]. O Atlântico e uma vida gloriosa de sol e de luz interpuseram-se entre nós e os mitos que saem imediatamente do solo em que vivem o francês, o inglês, o alemão e o italiano e em que viveram os seus antepassados. [...] A demonologia, como o decadismo, não encontra na alegria americana elementos que possam favorecer a criação de uma fase estética sombria e tenebrosa. (ARARIPE JÚNIOR, 1896, p. 132134)
}

A crença de que a paisagem natural brasileira seria incompatível com as diversas poéticas negativas configurou-se como um empecilho para a crítica literária conseguir identificar e analisar adequadamente tanto a tradição gótica quanto as narrativas decadentes em nossa ficção (cf. FRANÇA, 2017; SILVA, 2019). Por causa dessa falsa dicotomia, as obras que se valiam de topoi das duas formas artísticas receberam, muitas vezes, avaliações pejorativas, já que não teriam elementos tipicamente nacionais e careciam da chamada "cor local”. Assim, elas foram, sistematicamente, tratadas como meras imitações de produções estrangeiras. Ao descrever, não sem um juízo de valor desfavorável, a morbidez e o pessimismo veiculados por boa parte da literatura fin-de-siècle, Araripe Júnior (1896, p. 136) entende esses aspectos na produção de Coelho Neto como uma importação de tendências europeias, de bases, sobretudo, francesas: "Ora, seria um cúmulo que nós agora fôssemos também participar desse mal-estar 
de almas penadas, só por ouvir dizer que em Paris há escritores que se estão deixando tomar de medo dos habitantes da sombra e dos espíritos de seus antepassados".

Como resultado dessa opção artística, surgiria uma literatura falsa e desconectada da realidade brasileira. A importância de uma arte de base nacional se estabelece como um critério tão estruturante para a avaliação do mérito das narrativas que Araripe Júnior (1896, p. 136) chega a perguntar retórica e ironicamente: “Quem é Satã? Nós não o conhecemos; Satã não chegou a atravessar o Oceano. Já houve nacional que entretivesse relações com alguma bruxa?”. É relevante apontar, ainda, a instabilidade terminológica utilizada pelo crítico para definir esse tipo de ficção, variando entre "demonismo", "demonologia", "decadismo", "psicologia fantástica" e "sobrenaturalismo patológico". Apesar de todas essas nomenclaturas serem vistas com desconfiança, a conclusão é, surpreendentemente, positiva. Mesmo após investir contra a morbidez desses ideais artísticos, o crítico faz concessões ao caso de Coelho Neto, em especial a $O$ Rei Fantasma (1895) e aos contos de Praga (1896). Por mais que o autor tivesse se deixado seduzir por cenários orientalistas e fabulações macabras, seus livros tiveram valor pelo talento do romancista, pelo domínio estilístico, pela capacidade de entreter os leitores e, paradoxalmente, até mesmo por sua originalidade.

Após defender o aspecto de imitação dessas primeiras obras de Coelho Neto, Araripe Júnior (1896, p. 139) identifica quais autores teriam oferecido ao autor os recursos estilísticos e as temáticas originais, ao defini-lo como "[p]ossuidor de uma imaginação impregnada dos resíduos arqueológicos do Oriente, diluída na leitura de Flaubert, de Hoffmann, de Poe e de Huysmans". Embora, no caso do crítico oitocentista, essas filiações sejam entendidas sob o ponto de vista da importação de procedimentos narrativos e textuais, é importante ressaltar que grande parte do ideário artístico das obras dos escritores citados constitui, justamente, as bases da poética decadente e estão intimamente relacionadas à história da ficção gótica. Trabalhos recentes têm indicado, ainda, diversas aproximações entre as narrativas do maranhense e o gótico (cf. SILVA, 2006; MENON, 2007; CASTRO, 2017).

Como Coelho Neto, diversos outros escritores do período - não apenas brasileiros -, valiam-se das mesmas concepções estéticas para compor suas narrativas. Em vez de entender os diálogos intertextuais em termos de dívida e de imitação, é mais factual constatar como os romancistas do final do século XIX buscaram soluções artísticas semelhantes para expressar ansiedades comuns à própria experiência da modernidade, às querelas estéticas em voga e aos receios de degeneração. Longe de constituir mera veleidade, o imaginário orientalista, estruturante das diferentes categorias narrativas de $O$ Rei Fantasma, funciona como uma forma 
produtiva de explorar o artificialismo de temas e de linguagem e o exotismo tão caros à poética da decadência. Permite, igualmente, a utilização dos procedimentos do gótico na ficcionalização de uma sociedade supostamente bárbara, afeita à violência, composta por personagens monstruosas, repleta de loci horribiles e caracterizada por segredos misteriosos.

\section{A decadência de um reino não muito distante}

O enredo de $O$ Rei Fantasma se desenvolve a partir da história do rei Amany, monarca da cidade de Ziar, no antigo Egito, cujo estado físico e mental se deteriora progressivamente conforme constata as injustiças existentes em seu reino e o enorme sofrimento da população. Diversos atributos conferidos ao personagem são, essencialmente, os de um protagonista decadente, assemelhando-se, em alguns aspectos, a Des Esseintes, idealizado por Joris-Karl Huysmans em Às Avessas (1884). Trata-se de um aristocrata, psicologicamente instável e paranoico, avesso ao contato de mulheres e que pode ser entendido como o representante da degeneração e do esgotamento de sua dinastia. Apesar da indiferença e do individualismo patentes na maior parte das figuras decadentes, Amany possui uma certa consciência social, pois se horroriza ao perceber os efeitos da escravidão e as disparidades de uma comunidade regida por castas monárquicas ${ }^{5}$. Segundo Paulo Coelho Neto (1958, p. LXXIX), filho do autor, perante tal conjunto de características, "viram alguns uma sátira a Dom Pedro II, quando o que havia no capítulo era forte influência do Rei Lear". A despeito do modelo, o rei sofre com o ennui da vida na corte e com a avaliação de ser incapaz de modificar os problemas de Ziar.

Em quase todos os capítulos do romance, há cenas de violência explícita, concebidas justamente para ressaltar o sofrimento do povo e contrastá-lo com a apatia de Amany. Grande parte delas ocorre nos eventos públicos aos quais o monarca comparece, como festas em honra aos deuses ou feiras livres. A partir de uma narração heterodiegética, enfatizam-se mais os aspectos das multidões submetidas a diferentes torturas que o destino de personagens específicos. Recorrentemente empregada, tal estratégia narrativa reafirma a mensagem de degradação de uma sociedade e de um universo profundamente corrompido, para além da fraqueza individual do protagonista. Essa é uma tendência da ficção do final do século XIX, pois, como explica novamente Arata (1996, p. 1), é quando "narrativas heroicas de fundação

\footnotetext{
${ }^{5}$ A escravidão é um dos temas recorrentes da obra de Coelho Neto. Enquanto em O Rei Fantasma (1895), o protagonista é um monarca inapto em desfazer os horrores do sistema escravocrata, no romance Rei negro (1914), enfatiza-se a vingança do escravo Macambira - descendente de reis africanos - contra as violências dos senhores da fazenda.
} 
dão lugar a histórias sobre o fim dos tempos". Às passagens sobre as origens de Ziar e os feitos dos antepassados contrapõem-se a languidez de Amany e o seu sentimento de deterioração.

Embora o romance seja ambientado em um Egito fantasioso e temporalmente afastado do público oitocentista, é inevitável aproximar as suas descrições dos cruéis tormentos infligidos aos escravos de Ziar à própria escravidão praticada no Brasil até 1888. Ao apontar para a decadência de um reinado em um romance de inspiração orientalista, Coelho Neto oferece, ao mesmo tempo, um espelho das próprias estruturas escravocratas que vigoravam em nosso país até poucos anos antes da publicação da narrativa. Como indica Fernando Monteiro de Barros (2016, p. 1), a escravidão e o passado colonial do país são continuamente abordados no gótico brasileiro, caracterizado por obras que destacam a "ruína alegórica do Brasil patriarcal pré-republicano e pré-moderno". Nesse sentido, percebe-se como a ficção decadente e a gótica - recorrentemente taxadas de alienadas por parte da historiografia literária brasileira - possuem um lado político e veiculam avaliações críticas sobre problemas bastante reais.

Para analisarmos como os procedimentos do gótico e da decadência, elencados na parte inicial do artigo, configuram-se no romance, selecionamos três passagens de diferentes momentos da trama. Desse modo, é possível acompanhar tanto a variedade de situações pautadas por efeitos de recepção negativos quanto a própria evolução das ações. A primeira das cenas escolhidas ocorre no terceiro capítulo, quando se narra a ida do exótico cortejo de Amany à Ilha de Peh'ú durante um festival para celebrar a primavera. Grande parte da ação é apresentada a partir de analepses, responsáveis por oferecer aos leitores informações da terrível história do local, cujo passado destrutivo parece nunca ter sido superado. Mesmo no presente da narrativa, trata-se de um locus horribilis, onde até a natureza é degenerada: "De longe em longe um cacto disforme desgarrava os braços túmidos e espinhosos, cheios de grossas línguas marcadas de cicatrizes" (COELHO NETO, 1895, p. 99). Descrições de espaços naturais com características doentias são, aliás, recorrentes na ficção decadente (cf. SILVA, 2019).

Em suas origens, o lugar fora destinado a ser um presídio, no qual os condenados eram deixados para morrer de fome e, eventualmente, acabavam praticando o canibalismo. Em seguida, tornara-se um espaço de recebimento de vítimas de uma epidemia que assolara Ziar. Também esquecidos e destinados à morte, os doentes eram devorados por crocodilos, e seus cadáveres ficavam expostos à ação de aves carniceiras. $\mathrm{O}$ ataque dos animais, desmembrando o corpo dos enfermos, também é apresentado em detalhes pela narração, em uma sequência de mais de quatro páginas. No trecho a seguir, fica patente não apenas como a ilha se transforma 
em um local aterrador, mas também como o passado do lugar continua a influenciar negativamente o presente, sobretudo pelas marcas físicas deixadas por anos de destruição:

A misericórdia de Ísis pôs termo a esse triste sacrifício humano; a Peste locupletouos e abandonou os muros da cidade, mas o povo, desde então, nunca mais olhou para essa ilha alva e erma sem pavor, sem repugnância. Às vezes, caminhando-se pelos campos, tropeçava-se e um osso saltava da terra, lívido. Crânios rolavam nas praias promiscuamente com as conchas dos moluscos. [...] Justamente a leste, onde as caravanas de tráfico acampavam, havia uma caverna cheia de esqueletos de antigas vítimas, que ali haviam perecido de frio e de fome, encolhidas num conclave macabro. Ninguém ousava chegar ao limiar da furna - o terror guardava esse hipogeu soturno. (COELHO NETO, 1895, p. 104-105)

No plano diegético principal, Peh'ú funciona como um grande mercado de venda de escravos. Nessa parte da trama, enfatiza-se como o sistema escravocrata produz horrores e degrada a humanidade. Primeiramente, a narração exibe o flagelo de um homem negro por dois carrascos, barbárie que tem como resultado a extração de um dos olhos da vítima e a perfuração de seu ventre com uma lança. Ao redor do homem, outras vítimas acompanham, aterrorizadas, a tortura. Na sequência, ganha destaque a maneira pela qual ocorria a separação das famílias durante o comércio de cativos. Não apenas a violência física e as etapas dos assassinatos são descritas no trecho, mas também o próprio drama humano das mães separadas de seus filhos e o daqueles que decidiam tirar a própria vida para escapar dos algozes:

\footnotetext{
Mulheres corriam nuas, desesperadas, enchendo os ares de súplicas, perseguindo os homens que lhes arrebatavam dos peitos maternais os filhos pequeninos para que não lhes deformassem o corpo; alguns, importunados pelos clamores aflitos, brandiam as crianças, tomando-as por uma perna, esmigalhavam-lhes os crânios moles de encontro às pedras e voltavam-se tranquilamente entregando às mães cadáveres mutilados. As mulheres paravam hirtas, petrificadas na atitude súplice em que iam, olhavam sem choro, num êxtase de horror; de repente, arrojavam-se tomando nos braços a massa de carne e de sangue e partiam a correr, abraçadas com elas, bramindo e invocando desesperadamente os deuses da sua crença. [...] Não raro os guardas acudiam em tropel amotinado a um ponto, atraídos pelo alvoroto e encontravam um suicida expirando - procuravam a arma, mas os companheiros aterrados explicavam que ele se havia servido das próprias unhas para arrebentar a carótida. (COELHO NETO, 1895, p. 109-111)
}

Aliada à exposição da degradação corporal à qual são submetidas as crianças, a reação das personagens - "hirtas", "petrificadas" e "num êxtase de horror" - oferece indícios textuais para que a recepção tenha consciência de que a cena foi concebida para ser interpretada em sua dimensão aterrorizante. Outro aspecto relevante da passagem é a menção de que os homens agiam "tranquilamente" ao devolverem às mães o cadáver dos filhos, o que marca a desumanização dos captores e evidencia a crueldade do ato. Confrontado com esse cenário, a reação de Amany é, no mínimo, ambígua: fica impactado com o horror da ilha e dos assassinatos, mas autoriza o comércio de escravos. Na continuação do romance, o protagonista 
revela ao conselheiro Malayat seu desejo de ver a escravatura abolida, e recebe como resposta uma série de objeções por parte do súdito. O que parece ao rei particularmente excessivo não é exatamente a existência de escravos, considerados até mesmo úteis para o cultivo da terra, mas sim a violência envolvida em sua exploração. Exibida na dimensão de sua crueldade, a escravidão contribui para o agravamento do estado de saúde mental de Amany e explicita a sua tibieza de caráter, que, apenas na parte final da narrativa, será modificada.

A segunda cena selecionada para examinarmos a confluência entre gótico e decadência no romance ocorre em seu quinto capítulo, intitulado "A panegíria de Ísis". Nessa etapa da trama, Amany está cada vez mais isolado do contato social e precisa lidar com os boatos, existentes entre a população de Ziar, de que enlouquecera. Para dispersar os rumores, o monarca é aconselhado a participar dos rituais em homenagem à deusa. Ao fazê-lo, o protagonista surpreende-se, mais uma vez, com a realidade, pois os festejos são caracterizados como uma ocasião de desregramento para os habitantes do reino. Ao longo dos seis dias de comemoração, ocorrem desfiles pomposos, repletos de objetos ritualísticos, animais e diversas fanfarras. Novamente, a narração apresenta o evento sob um ponto de vista coletivo, para demarcar o exotismo dos cultos e o descontrole das personagens. Nesse ponto, a violência adquire um caráter tanto religioso quanto sexual e as figuras têm seus aspectos monstruosos sublinhados:

Fanáticos talhavam artérias e ofereciam o sangue quente aos ídolos; alguns ajoelhavam-se e sorviam as feridas dos companheiros numa comunhão bárbara. [...]

Negros saracoteavam agarrados aos ídolos hediondos, outros seguindo a crença de um vizinho acocoravam-se mirando fetiches desconhecidos, tocavam-lhes os membros, riam imbecilmente e faziam votos à divindade estranha, esquecendo em abandono sobre as folhas o manipanso borrifado de lama. Alguns, vermelhos de sangue, sacrificavam animais em altares toscos. Mulheres entregavam-se sensualmente ao primeiro vindo e deixavam-se estar rolando pela terra e bramando como as leoas no tempo do amor; outros vinham e elas passivamente, arquejando, abriam-lhes os braços. Formavam-se grupos em torno do casal, e o amor era aplaudido como uma sorte ágil de acrobata. (COELHO NETO, 1895, p. 168; p. 183)

A partir dessas descrições, observa-se como a comunhão religiosa inclui também as pulsões sexuais e, de forma mais específica, a degradação corporal. Como observamos anteriormente, essa representação negativa e bestial da sexualidade configura-se como uma das recorrências do gótico e da decadência. Observa-se, ainda, uma qualificação negativa dos rituais, já que os participantes são "fanáticos”, que tomam o sangue de feridas, "imbecilmente", em nome a deuses "hediondos", celebrados em altares "toscos". A continuação dos festejos inclui, até mesmo, a descrição de pessoas que, bêbadas, mutilavam-se com adagas e perdiam seus intestinos. Tais trechos reforçam a ideia de que as narrativas finisseculares tendem a 
explorar mais intensamente a violência em espaços ficcionais caracterizados como bárbaros e distanciados temporalmente da contemporaneidade oitocentista. Esses mesmos procedimentos são verificados nas interfaces da produção regionalista de Coelho Neto com o gótico, sobretudo nas passagens em que se descrevem as práticas espirituais e a sexualidade de personagens negros e mestiços - apresentadas como atrasadas e pouco civilizadas (cf. CASTRO, 2017).

A terceira passagem escolhida para exemplificar os procedimentos góticos e decadentes encontra-se no sexto capítulo da obra. Ao consultar um mago capaz de interpretar as posições dos planetas para fazer previsões, Amany recebe maus prognósticos sobre a continuação de seu reino, para sua própria vida e para o futuro de seu frágil filho. Após o encontro com o astrólogo, o rei torna-se mais pessimista e enfraquecido. Para explicar o próprio abatimento, o protagonista faz referência, em passagens anteriores, a um dos principais tipos de personagem da tradição gótica, ao pedir ao seu conselheiro que o deixe sozinho: “- [...] Deixa-me em tréguas, não queira ser cúmplice do vampiro que durante as noites suga minh'alma, deixando nela o veneno do remorso e do horror de mim mesmo" (COELHO NETO, 1895, p. 77-78).

Descrevendo-se também como um escravo, preso em seu próprio território e cercado por possíveis inimigos, o rei se depara com um grupo de mulheres que o aguardam em um gineceu. Em um encontro com Tamat, uma das concubinas, marcado ora pela atração, ora pela repulsa, o protagonista faz um longo discurso clamando pelo fim de todas as coisas. Sua fala ganha intensidade progressivamente, até que, de repente, ele cai desacordado sem motivo aparente. Com o barulho da queda, os guardas entram no cômodo e, ao não verificarem mais sinais vitais no monarca, anunciam a sua morte. A culpa pelo pretenso homicídio recai sobre a sua amante, condenada a ser devorada por leões. A pena é executada imediatamente:

[...] A leoa, d'um salto, atirou-se à anca do leão e, n'outro salto, fugiu, e houve, no mesmo instante, um grito forte e rápido, e o corpo de Tamat debateu-se um momento. Desprenderam-se-lhe os braços e um jorro de sangue escorreu pelo peito louro do leão que baixava levando o corpo mole entre as presas. A leoa aproximou-se de rastro e as duas feras, enquanto os eunucos saltavam grugrulhando, numa alegria bárbara, deitaram-se - o leão com o corpo frio entre as patas, rosnando e rosnando também a leoa, em frente. Por fim, o leão, como se raspasse, rasgou com a pata o ventre virgem e levantando a cabeça rugiu vitoriosamente; a leoa, vendo-o d'olhos altos, abocanhou a gorja e, num safanão, separou do tronco a formosa cabeça da concubina egípcia. (COELHO NETO, 1895, p. 221)

Além do brutal desmembramento de Tamat, enfatizado pela descrição minuciosa de seu suplício físico, chama atenção a espetacularização da pena. Não apenas o corpo da moça, injustamente condenada, torna-se um mero brinquedo para os leões, como também a cena é acompanhada com "alegria bárbara" pelos eunucos, que "saltavam grugrulhando". Mais uma 
vez, reforça-se a crueldade das personagens, sua monstruosidade moral e o aspecto arcaico daquela sociedade.

O episódio da morte de Tamat marca a passagem para os capítulos finais do romance. Com a cidade prestes a ser invadida por inimigos, Amany surpreende seus cuidadores mais próximos ao acordar de repente: não havia morrido, mas caíra em um estado de catalepsia, motivado pelo enfraquecimento de seus músculos, que persistira por três dias e três noites. Decidindo não informar a seus conselheiros a verdade, o personagem aproveitará da condição de "fantasma" para inspirar o povo na guerra, como se possuísse poderes sobrenaturais. Assim, o rei ordena a um de seus súditos: "- Vai! Ouve bem e guarda as minhas palavras; Amany, rei de Saidah, não existe. Quem vai levar as tropas a combate é o espectro do rei” (COELHO NETO, 1895, p. 239). Após o fim do conflito, com a surpreendente vitória de suas tropas, ele se aproveita do status de morto para desaparecer misteriosamente, afastando-se das funções monárquicas e tornando-se um asceta.

Com a explicação racional para um evento de possível interpretação sobrenatural - a morte misteriosa do rei -, observamos que o "fantasma" do título ganha outra conotação. Não se trata verdadeiramente de um ser espectral, mas de alguém que, por fraqueza e aversão às estruturas sociais de seu reino, prefere se declarar morto e afastar-se da vida em sociedade. É importante destacar, ainda, que o procedimento conhecido como "sobrenatural explicado" foi sistematicamente empregado pela tradição gótica e, em especial, por Ann Radcliffe (cf. BYRON \& PUNTER, 2004). Apesar de se aproximar, nesse ponto, da literatura gótica setecentista, Coelho Neto promove uma releitura em outro aspecto. Tendo em vista a degeneração física e psicológica do protagonista, Amany pode ser entendido como uma versão decadente, fin-de-siècle, do célebre Vathek, protagonista do romance homônimo de Beckford ${ }^{6}$. Enquanto este é caracterizado por sua enorme crueldade e sede de poder - a ponto de fazer um pacto com figuras demoníacas - aquele, pelo contrário, mostra-se como um monarca vencido pelo spleen, às voltas com suas crises de nervos e ávido pela própria morte.

Finalmente, outro aspecto essencial da ficção decadente na obra, potencializado pelo imaginário orientalista, é a experimentação linguística, indicada na primeira seção deste trabalho como um dos elementos mais importantes para a decadência. No romance de Coelho Neto, há diversas passagens repletas de termos raros e relacionados ao ambiente cultural

\footnotetext{
${ }^{6}$ Uma comparação semelhante foi sugerida por Jorge Luis Borges (2017, p. 13), quando apontou a figura de Vathek como precursora, entre outros tipos, de Des Esseintes, protagonista de Às Avessas, em razão da excentricidade e do apreço por sensações impactantes compartilhados pelos dois. O personagem de Huysmans, por outro lado, é o símbolo por excelência do mal-estar finissecular.
} 
egípcio. A partir de descrições de vestimentas, acessórios, hábitos, crenças e espaços geográficos da região de Ziar, a narrativa adquire uma forma discursiva hermética, já que parte do léxico não compunha o conjunto de usos correntes do português brasileiro oitocentista. A própria ambientação suntuosa e luxuosa, recorrente nesse tipo de narrativa, propicia o desenvolvimento de um estilo ornamental, típico da decadência, cioso dos detalhes de cores, formas e reflexos. No trecho a seguir, os vocábulos destacados revelam o preciosismo textual e o exotismo:

E surgiram gravemente as palácides nas suas túnicas finíssimas e diáfanas como de névoa, os braços cruzados guardando junto ao colo pequenas liras piriformes [...]. Depois o sam, o grande sacerdote, lento, os olhos no céu; padres de Osíris, de lavas túnicas roçagantes coberturas por uma pele de pantera; outros com estranhas máscaras de chacal, como Anúbis, o deus funerário ou com cabeças de leoa como Sekhet; aulétrides e harpistas com altos tebunis em arco; flabelíferos, sustendo grandes pálios flácidos de plumas de pavão, e ficaram parados e firmes como os deuses que apareceram a Bata [...] (COELHO NETO, 1895, p. 30-31. Destaques meus).

Considerado pela crítica como um simples romance de entretenimento, O Rei Fantasma evidencia uma estrutura mais complexa, quando analisado sob a ótica da confluência entre as poéticas gótica e decadente. Ao voltar-se para o imaginário orientalista, ressaltando tanto aspectos exóticos quanto bárbaros, Coelho Neto desenvolve um livro marcado pela violência do início ao fim. A partir de recursos narrativos e estilísticos tributários do gótico e da decadência, o escritor consegue impactar diretamente o público-leitor e gerar efeitos de recepção negativos. Sem abrir mão da fabulação imaginativa, por vezes mística e com passagens de sugestão sobrenatural, a narrativa trata também de temas bastante reais. Mesmo negada pelo filho do autor, é possível fazer uma leitura alegórica do romance, aproximando a situação de Amany à do imperador Dom Pedro II. Conclui-se que a degradação surge como o tema principal do texto, explicitada pelas práticas escravocratas, pela crueldade das personagens e pelo esgotamento físico e psicológico do protagonista. Assim, observamos como a decadência do reino de Amany e a sua percepção de degeneração individual e coletiva não são assim tão distantes e desconhecidas do Brasil do final do século XIX.

\section{REFERÊNCIAS}

ARARIPE JÚNIOR. Movimento de 1893: o crepúsculo dos povos. Rio de Janeiro: Tipografia da Empresa Democrática Editora, 1896. 
ARATA, Sthephen. Fictions of Loss in the Victorian Fin De Siècle: Identity and Empire. New York: Cambridge University Press, 1996.

ASSIS, Machado de. A Semana. In: Gazeta de Notícias, Rio de Janeiro, 08 de setembro de 1895, p. 1.

BARROS, Fernando Monteiro de. A alegoria e o fantasma no Gótico brasileiro: Cornélio Penna e Lúcio Cardoso. In: Anais eletrônicos do XV encontro da ABRALIC. Rio de Janeiro: Dialogarts, 2016, p. 2472-2482.

BORGES, Jorge Luis. Prólogo 2. Tradução de Maria da Gloria Lampreia. In: BECKFORD, William. Vathek. Tradução de Henrique de Araújo Mesquita. Porto Alegre: L\&PM, 2007.

BROCA, Brito. Nota preliminar. In: COELHO NETO. Obra seleta; romances, v. 1. Rio de Janeiro: Editora José Aguilar, 1958.

BYRON, Glennis. Gothic in the 1890s. In: PUNTER, David (Org.). A New Companion to the Gothic. Sussex: Blackwell Publishing, 2012, p. 186-196.

; PUNTER, David. The Gothic. Oxford: Blackwell, 2004.

CASTRO, Hélder Brinate. A Praga do Sertão: aspectos do Gótico em Coelho Neto. In: SILVA, Alexander Meireles da; BARROS, Fernando Monteiro de; FRANÇA, Júlio; COLUCCI, Luciana. (Org.). Estudos do Gótico. Rio de Janeiro: Dialogarts, 2017, p. 65-74.

COELHO NETO. O Rei Fantasma. Rio de Janeiro: Livraria Moderna, 1895.

COELHO NETO, Paulo. Imagem de uma vida. In: COELHO NETO. Obras seletas; romances, v. 1. Rio de Janeiro: Editora José Aguilar, 1958, p. LXXXIII-CVI.

FRANÇA, Julio. O sequestro do Gótico no Brasil. In: FRANÇA, Julio; COLUCCI, Luciana. (Org.). As nuances do Gótico: do Setecentos à atualidade. Rio de Janeiro: Bonecker, 2017, p. 111-124.

LUCKHUSRT, Roger. Transitions: From Victorian Gothic to Modern Horror, 1880-1932. In ALDANA REYES, Xavier. Horror; a literary history. London: British Library, 2016, p. 102129.

MENON, Mauricio César. Figurações do gótico e de seus desmembramentos na literatura brasileira; de 1843 a 1932. Tese (Doutorado em Letras). Faculdade de Letras, Universidade Estadual de Londrina, Paraná, 2007.

PIERROT, Jean. L'Imaginaire décadent (1880-1900). Rouen: Publications des Universités de Rouen et du Havre, 1977.

PUNTER, David. The Literature of Terror: a History of Gothic Fictions from 1765 to the present days. The Modern Gothic. Longman: London and New York, 1996. 
SILVA, Alexander Meireles da. "Transexualismo e literatura gótica em Esfinge, de Coelho Neto”. In: Gênero e Preconceitos. Universidade de Santa Catarina, 2006.

SILVA, Daniel Augusto P. A prosa de ficção decadente brasileira e francesa (1884-1924): uma poética negativa. Dissertação (Mestrado em Teoria da Literatura e Literatura Comparada) - Instituto de Letras, Universidade do Estado do Rio de Janeiro, Rio de Janeiro, 2019.

STEAD, Evanghélia. Le monstre, le singe et le foetus: Tératogonie et Décadence dans l'Europe fin-de-siècle. Genèvre: Droz, 2004.

Recebido em 21/8/2020.

Aceito em 18/11/2020. 